\title{
Cell Membrane-Interrupting Antimicrobial Peptides from Isatis indigotica Fortune Isolated by a Bacillus subtilis Expression System
}

\author{
Jia Wu ${ }^{1}$, Hafiz Muhammad Khalid Abbas ${ }^{2,3}$, Jiale Li ${ }^{1}$, Yuan Yuan ${ }^{4}$, Yunjun Liu ${ }^{5}$, \\ Guoying Wang ${ }^{5}(\mathbb{D}$ and Wubei Dong $1, *(\mathbb{B})$
}

1 Department of Plant Pathology, College of Plant Science and Technology and the Key Lab of Crop Disease Monitoring \& Safety Control in Hubei Province, Huazhong Agricultural University,

Wuhan 430070, Hubei Province, China; wj123@webmail.hzau.edu.cn (J.W.); lj10410@webmail.hzau.edu.cn (J.L.)

2 Vegetable Research Institute, Guangdong Academy of Agricultural Sciences, Guangzhou 510640, China; khalid_mpp@hotmail.com

3 Guangdong Key Laboratory for New Technology Research of Vegetables, Guangdong Academy of Agricultural Sciences, Guangzhou 510640, China

4 National Resource Center for Chinese Materia Medica, China Academy of Chinese Medical Sciences, Beijing 100700, China; y_yuan0732@163.com

5 Institute of Crop Science, Chinese Academy of Agricultural Sciences, South Street of Zhongguancun 12, Beijing 100081, China; liuyunjun@caas.cn (Y.L.); wangguoying@caas.cn (G.W.)

* Correspondence: dwb@mail.hzau.edu.cn; Tel.: +86-150-0710-94-36

Received: 22 September 2019; Accepted: 16 December 2019; Published: 24 December 2019

\begin{abstract}
The situation of drug resistance has become more complicated due to the scarcity of plant resistance genes, and overcoming this challenge is imperative. Isatis indigotica has been used for the treatment of wounds, viral infections, and inflammation for centuries. Antimicrobial peptides (AMPs) are found in all classes of life ranging from prokaryotes to eukaryotes. To identify AMPs, I. indigotica was explored using a novel, sensitive, and high-throughput Bacillus subtilis screening system. We found that IiR515 and IiR915 exhibited significant antimicrobial activities against a variety of bacterial (Xanthomonas oryzae, Ralstonia solanacearum, Clavibacter michiganensis, and C. fangii) and fungal (Phytophthora capsici and Botrytis cinerea) pathogens. Scanning electron microscope and cytometric analysis revealed the possible mechanism of these peptides, which was to target and disrupt the bacterial cell membrane. This model was also supported by membrane fluidity and electrical potential analyses. Hemolytic activity assays revealed that these peptides may act as a potential source for clinical medicine development. In conclusion, the plant-derived novel AMPs IiR515 and IiR915 are effective biocontrol agents and can be used as raw materials in the drug discovery field.
\end{abstract}

Keywords: antimicrobial peptide; plant resistance gene; membrane-interrupting peptides; gene expression system; Bacillus subtilis; Isatis indigotica

\section{Introduction}

Drug resistance in pathogenic microbes is an emerging challenge in crop production and human health care [1,2]. Multiresistant bacteria have many strategies that threaten the health of animals and plants [3], such as beta-lactamases that are enzymes synthesized by bacteria to break host resistance [4]. This situation has been provoked by the recent attention paid to identifying new antimicrobial genes against emerging bacterial resistance [5]. Therefore, scientists have been trying to discover novel biocontrol agents to overcome this problem. Antimicrobial peptides (AMPs) have received 
a considerable amount of attention because of their significant activity against fungi, bacteria, parasites, viruses, inflammation, and tumor cells [6,7]. It is generally believed that AMPs are short peptides (20-50 amino acids) with low molecular weight and mostly linear cationic $\alpha$-helices [8], with effective activity against a broad spectrum of pathogens. AMPs can be isolated from a variety of organisms such as bacteria, fungi, insects, plants, animals, and humans [9,10]. As a new class of antibiotic with low tendency to induce resistance, high antimicrobial activity, and good selectivity, AMPs have the potential to replace some traditional antibiotics in the future [11]. The Gram-positive bacterial cell envelope is composed of an outer cell wall (a thick peptidoglycan layer and a polysaccharide coat) and an inner cytoplasmic membrane. To achieve their bactericidal activities, AMPs interact with the cell wall or cytomembrane, resulting in membrane interruption and cell lysis [12]. In most of these cases, AMPs are reported to cause disruptions in cell wall or cell membrane integrity, perforation, deformation, and increased water ion and molecular flow across the membrane, which ultimately causes microbial death [13].

In biotechnology, Bacillus subtilis has been considered an effective tool to study high-level expression of foreign proteins [14]. Additionally, it is a generally regarded as safe (GRAS) organism that does not produce endotoxins [15]. Because of its relatively simple cell structure, high growth rate, short fermentation time, and high capacity to secrete proteins directly into the extracellular medium [16], it has long been successfully used for the expression of many protein products, including some industrial enzymes (proteases, lipases, and amylases) [17,18].

Isatis indigotica belongs to the Brassicaceae family and is a biennial herb that has been used as a traditional medicine to cure wounds in Europe and China for centuries [19]. Different compounds isolated from I. indigotica leaves have exerted anti-inflammatory and anti-allergic activities [20]. Extracts of I. indigotica hairy root cultures showed antioxidant activities [21]. Alkaloids isolated from I. indigotica exhibited inhibitory activities against two different types of ureases (Jack bean and Bacillus pasteurii ureases) and significant antifungal activity against Aspergillus niger, Candida albicans, Trichophyton schoenleinii, T. simii, and Macrophomina phaseolina [22].

To date, most of the research related to AMPs has been focused on extraction, separation, purification, and synthesis of AMPs, as well as some exploration of resistance mechanisms [23]. For the isolation of candidate AMPs, there are two main methods. One method is based on stepwise separation and detection of proteins or polypeptides after isolation from organisms directly [24]. Because the number of AMPs in microbes is usually limited, extensive losses can occur during the isolation and purification procedures. The second method is to synthesize AMPs artificially. This method can improve AMP efficacy and range of performance.

Two factors contribute to a bottleneck in plant resistance breeding — the scarcity of plant resistance genes and the fact that resistance genes are easily overcome by pathogens. To overcome the scarcity of plant resistance genes, we established an antimicrobial gene isolation method using a $B$. subtilis expression system [25]. To avoid the propensity for resistance genes to be overcome by pathogens, we designed a model in which pathogen-independent, nonself-recognition triggered, and heterosis-based fresh resistance can be generated in F1 hybrids [26]. To the best of our knowledge, I. indigotica has been less well documented for its antimicrobial potential. In the current study, novel AMPs were identified from I. indigotica using the B. subtilis expression system, and further studies were performed to explore their antibacterial and antifungal activities. To determine the basis of the host-pathogen interaction, the potential for these AMPs to control plant diseases and their mechanisms were also investigated in this study.

\section{Results}

\subsection{Candidate Genes from an Isatis indigotica cDNA Library Exhibited Antimicrobial Potential}

In an attempt to identify AMPs from I. indigotica, a cDNA library was constructed from purified mRNA using the pBE-S vector and B. subtilis expression system (Figure S1). We assumed that the 
expression and secretion of candidate genes from the cDNA library in B. subtilis cells would reveal the killing or damaging effects of the expressed products in their virulence against host cells. Based on this assumption, cells with abnormal growth were identified and their inserts were considered to be potential antimicrobial genes (Figure 1).
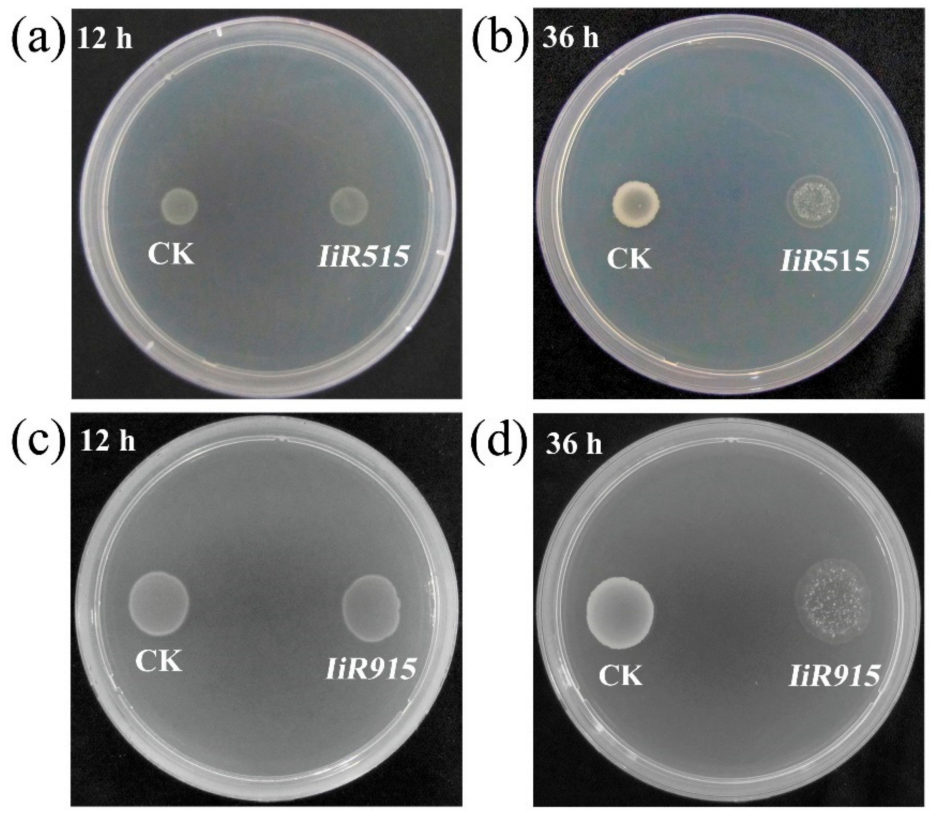

Figure 1. Damaging effect of foreign proteins on host Bacillus subtilis cells. The engineered B. subtilis strains harboring $I i R 515$, IiR915, and empty vector were separately spotted onto Luria-Bertani (LB) plates and incubated at $37{ }^{\circ} \mathrm{C}$. (a) IiR515 after $12 \mathrm{~h}$ of incubation and (b) after $36 \mathrm{~h}$ of incubation; (c) IiR915 after $12 \mathrm{~h}$ of incubation and (d) after $36 \mathrm{~h}$ of incubation. The empty vector-transformed B. subtilis strain (WB800-e) was used as a control. Spots on the right represent the test clones with damaging effects and spots on the left represent the control.

The lengths of the inserts were analyzed by polymerase chain reaction (PCR) (Figure S2), and the quality of the cDNA library was determined based on the primary library titer and recombination rate, which were $5.6 \times 10^{6} \mathrm{CFU} / \mathrm{mL}$ (Colony Forming Units per milliliter) and $90.27 \%$, respectively. During initial screening, a total of $2.20 \%$ of clones (45/2039) demonstrated killing effects on B. subtilis, and among them, 15 clones showed strong antimicrobial activities. These results suggested that the inserted fragments in those 15 clones coded for products with the potential to inhibit or kill microorganisms (Table S2). Based on this screening, IiR515 and IiR915 were selected for further study.

\subsection{Candidate Antimicrobial Peptides Destroyed the Cell Membrane of B. subtilis}

To determine the damaging effects of the functional peptides on the cytomembrane, scanning electron microscopy (SEM), confocal microscopy, and cytometric analysis were used to observe the cellular surface morphology and integrity (Figure 2). From the SEM results, the control B. subtilis WB800-e strain showed normal and intact cell morphology. By contrast, membrane damage, such as membrane holes, deformation, and lysis, was observed in cells transformed with the IiR515 and IiR915 genes (Figure 2a). Cell staining was observed by confocal imaging. Under an ordinary optical microscope, rod-shaped bacterial cells were observed for both the control and transformed strains (Figure 2b). However, images under a fluorescence microscope were different; red fluorescence was not observed for B. subtilis WB800-e (control), whereas obvious red rod-shaped IiR515- and IiR915-transformed bacteria were observed (Figure 2c). Propidium iodide (PI) uptake increases with an increase in cell membrane permeability. Dot plots showed that the B. subtilis WB800-e strain had 
minimal PI staining (approximately 1.75\%). Conversely, the PI fluorescent signal for the transgenic strains was much stronger, approximately $88.4 \%$ for IiR515 and 96.9\% for IiR915 (Figure 2d).

IiR515

(a)

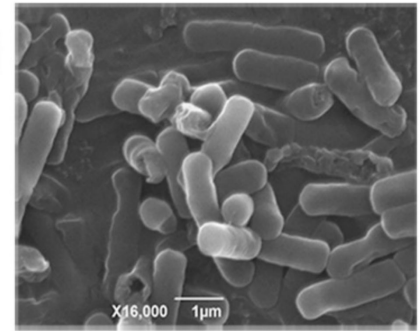

(b)

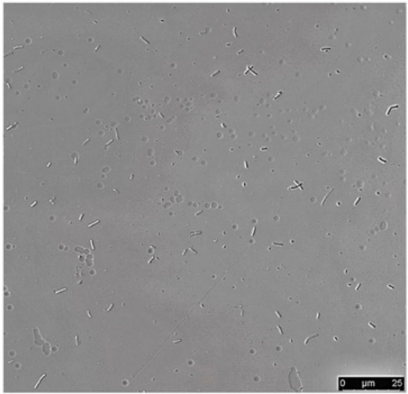

(c)

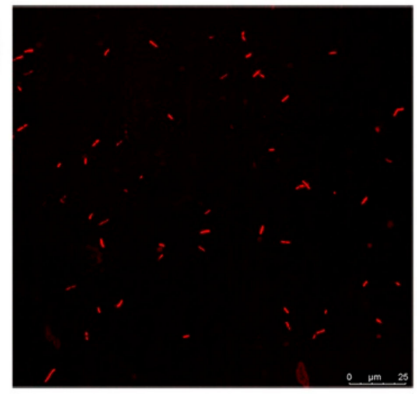

(d)

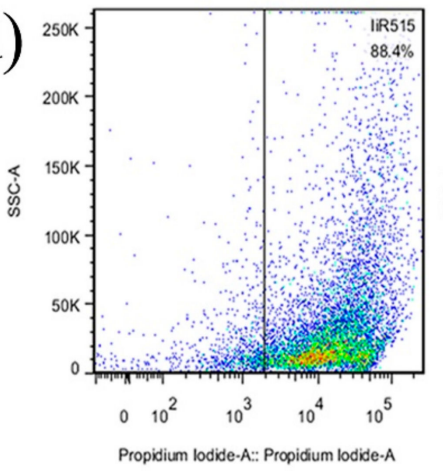

IIR915
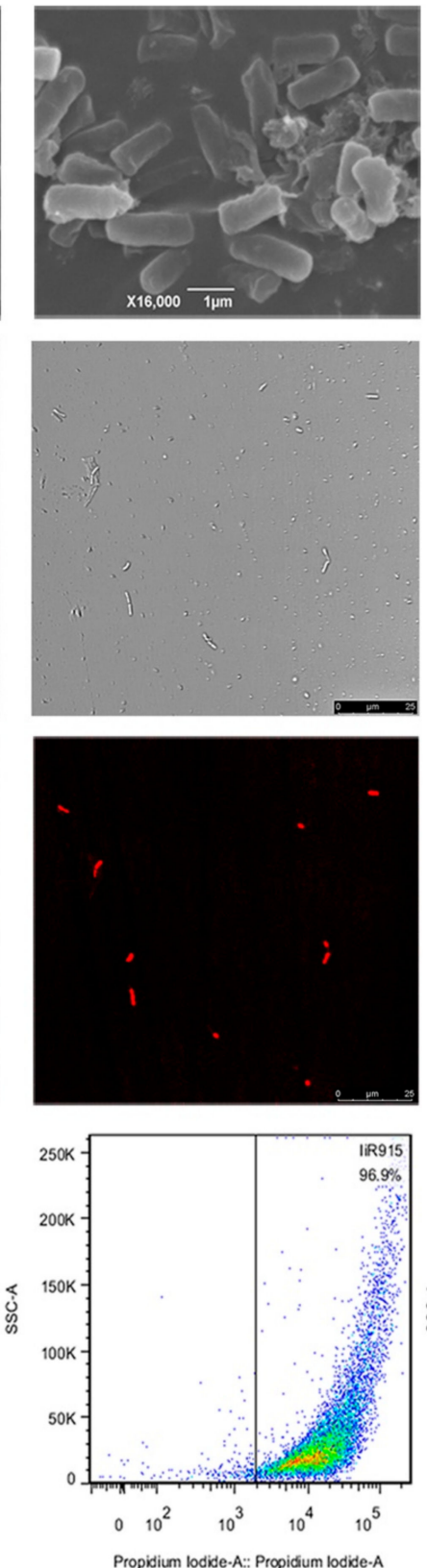

WB800-e
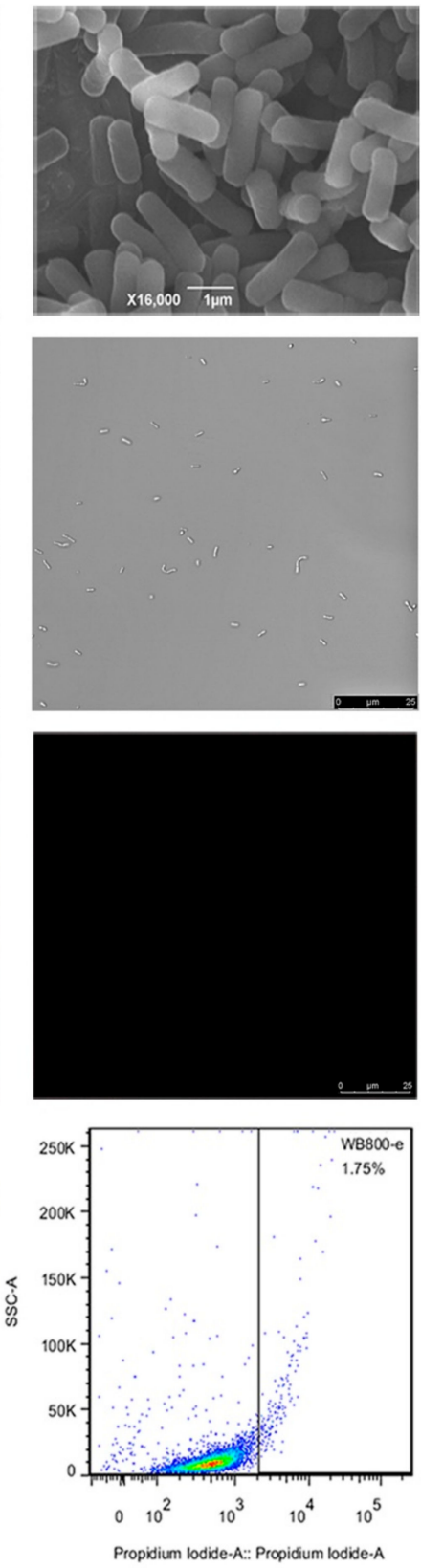

Figure 2. Cell membrane disruptions of transformed B. subtilis cells. Bacillus pellets were fixed with glutaraldehyde after washing with PBS buffer (phosphate buffer saline). Finally, the samples were lyophilized and then gold coated. (a) Cellular disruption of IiR515, IiR915, and WB800-e (empty vector-transformed B. subtilis WB800) under the scanning electron microscope. Test bacteria were washed and resuspended in PBS buffer at $1 \times 10^{9} \mathrm{CFU} / \mathrm{mL}$ and stained with PI $(40 \mathrm{mg} / \mathrm{mL})$. Confocal images under (b) ordinary light and (c) fluorescence. (d) Percentages of fluorescent events (relative value of PI staining) in gate shown in the region on the right. The $x$-axis shows the relative fluorescence intensity and the $y$-axis shows the side scatter light.

The $y$-axis shows the intensity of scattered light, which also increased with increased PI fluorescence signal ( $x$-axis). All of these results showed that the intact cell membrane of wild-type Bacillus rejected the infiltration of PI. By contrast, PI infiltration into the IiR515- and IiR915-transformed cells occurred 
because of their incomplete cell membranes and PI bound to their exposed nucleic acids, resulting in the observation of red fluorescence. Our results revealed that the cell membrane was significantly destroyed, ultimately leading to cell death.

\subsection{Candidate Antimicrobialpeptides Altered the Fluidity and Electrical Potential of the Bacillus subtilis Cytoplasmic Membrane}

For the further analysis of the integrity of the cytoplasmic membrane, the fluidity and electrical potential $(\Delta \Psi)$ of the cytoplasmic membrane were monitored. The DPH (1.6-diphenyl-1,3,5-hexatriene) fluorescent probe was used for orientation, predominantly parallel to the fatty acid chains, and reflected the fluidity of the core of the cytoplasmic membrane, while 3,3'-dipropylthiadicarbocyanine iodide $\left(\mathrm{DiSC}_{3}(5)\right)$ was used to detect perturbations of the electrical potential gradients across the cytoplasmic membrane. Our results showed that for IiR515- and IiR915-transformed Bacillus cells, the fluidity of the plasma membrane core was significantly reduced as time increased, but changes were not significant for the control WB800-e strain (Figure 3a). The $\mathrm{DiSC}_{3}(5)$ fluorescent probe was used to detect perturbations in electrical potential gradients across the cytoplasmic membrane, and we observed that changes in the electrical potentials of IiR515- and IiR915-transformed Bacillus cells were significantly higher than the control cells (Figure 3b).
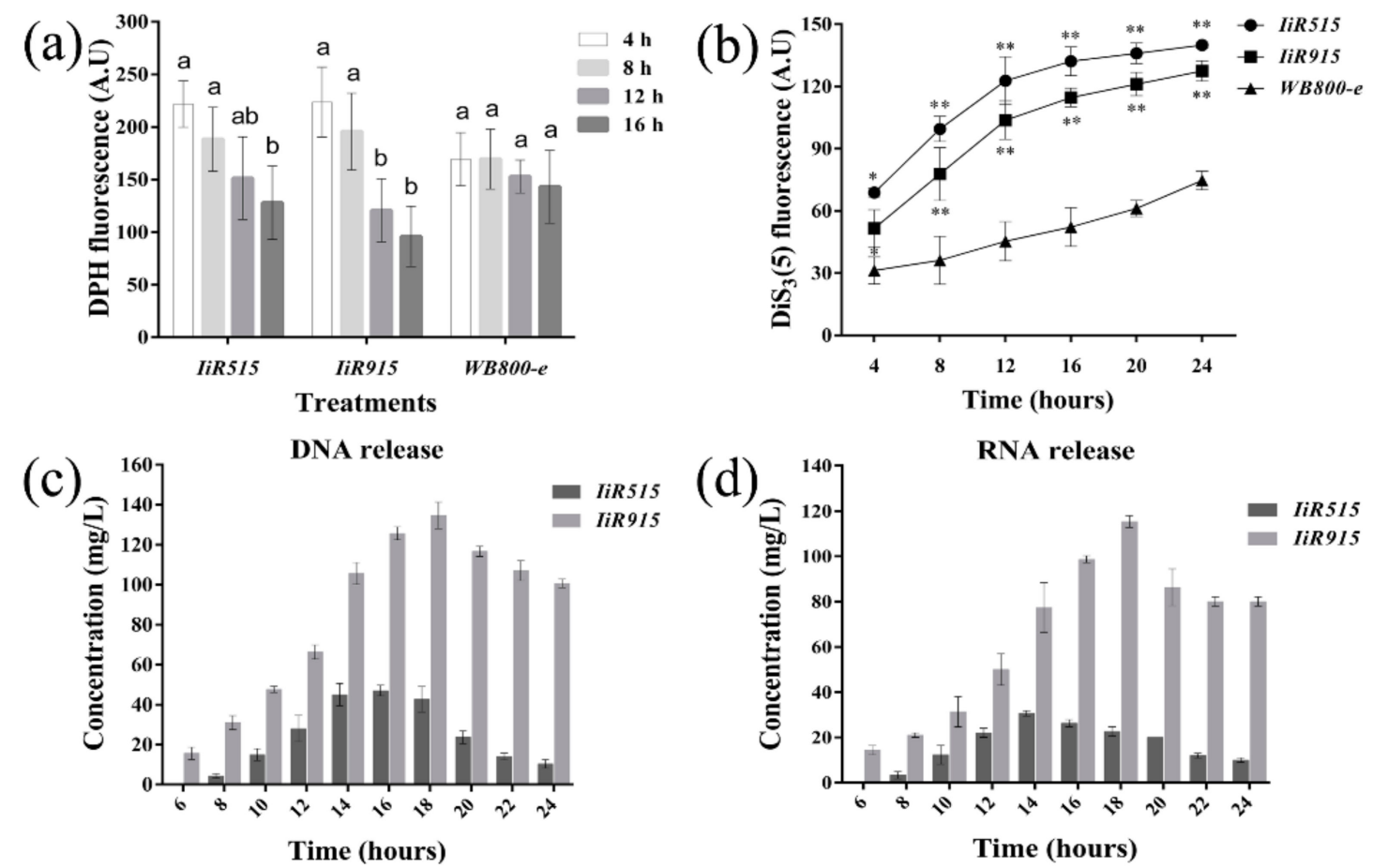

Figure 3. Fluorescence intensity and nucleic acid release of B. subtilis cells. The fluidity and electrical potential of the cytoplasmic membrane of B. subtilis were measured. Excitation and emission wavelengths for (a) The DPH were $365 \mathrm{~nm}$ and $425 \mathrm{~nm}$ and for (b) DiSC 3 (5) were $622 \mathrm{~nm}$ and $670 \mathrm{~nm}$, respectively. The WB800-e strain was used as a control. The detection of released DNA and RNA was also performed. The empty vector was used as a blank control. (c) The concentration of DNA and (d) RNA in shaking media at different time intervals. Data are the mean values from three individual experiments. Vertical bars represent the SD (Standard deviation). For significance analysis, $t$-tests were performed; ${ }^{*} p<0.05,{ }^{* *} p<0.01$.

\subsection{The Detection of DNA/RNA in Shaking Media Indicated Cell Membrane Breakage}

We assumed that if the membranes of transformed strains were damaged, then some of their components, such as nucleic acids (DNA and RNA), would leach out into the media. To prove this assumption, the total amount of released DNA and RNA was measured using an Eppendorf Bio 
Photometer. The results supported our hypothesis that IiR515 and IiR915 made pores in the cell membrane to release nucleic acids out into the media (Figure 3c). The highest amount of DNA was observed for IiR515 at the $16 \mathrm{~h}$ time point, whereas the highest levels for IiR915 were observed at the $18 \mathrm{~h}$ time point. A significant amount of RNA was also observed in the media at other time intervals (Figure 3d).

\subsection{Extracellular Peptides of IiR515 and IiR915 Exhibited Antimicrobial Activities}

Extracellular peptides of all candidate strains were extracted using the ammonium sulfate precipitation method and tested for their antimicrobial activities. The results revealed that the IiR515 and IiR915 peptides exhibited significant levels of inhibition against Gram-positive and Gram-negative bacteria as well as fungi compared to controls (Figure 4a,b and Figure S3). Thermal stability assays revealed that both peptides acted as stable antimicrobial agents against Gram-positive and Gram-negative bacteria at temperatures ranging from 4 to $100{ }^{\circ} \mathrm{C}$ (Figure $4 \mathrm{c}, \mathrm{d}$ ). After purification, the minimum inhibitory concentrations (MICs) of IiR515 and IiR915 were evaluated using the critical dilution method against Gram-positive (Clavibacter fangii and C. michiganensis) and Gram-negative (Xanthomonas oryzae and Ralstonia solanacearum) bacteria. Results indicated that the MICs of both peptides were less than $100 \mu \mathrm{g} / \mathrm{mL}$ (Table S4).
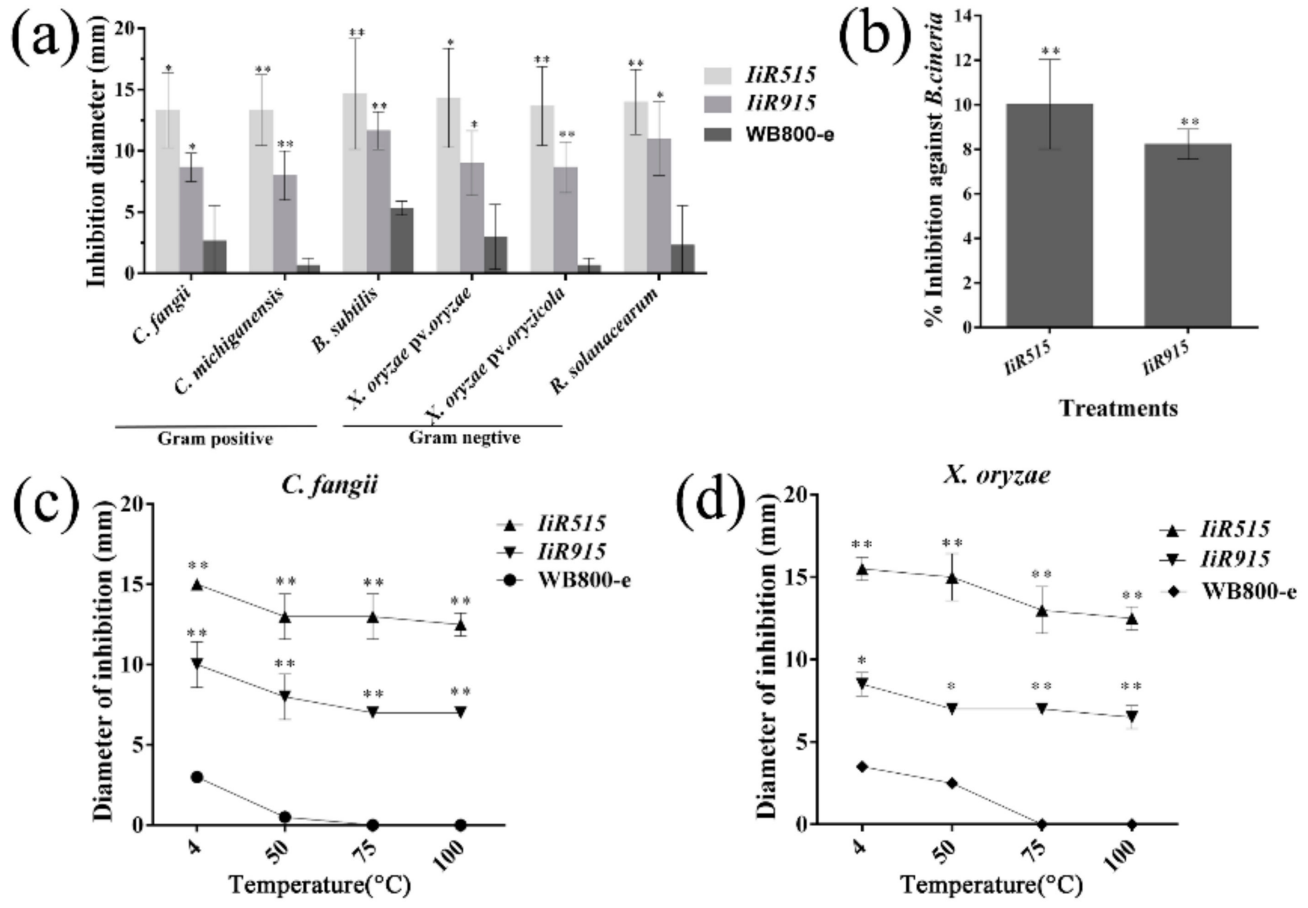

Figure 4. Analysis of potential antimicrobial peptides (AMPs) against pathogens. For antimicrobial activity assays, the B. subtilis WB800-e strain was used as a control. (a) Inhibition of Gram-positive and Gram-negative bacteria in response to IiR515 and IiR915 compared to WB800-e. (b) Percent inhibition of IiR515 and IiR915 against Botrytis cinerea compared to WB800-e. Temperature curves for (c) Clavibacter fangii and (d) Xanthomonas oryzae. Data are the mean values from three individual experiments. Vertical bars represent the SD. For significance analysis, $t$-tests were performed; ${ }^{*} p<0.05,{ }^{* *} p<0.01$.

\subsection{Western Blots Revealed the Expression and Size of the IiR515 and IiR915 Peptides}

His-tag fusion IiR515 and IiR915 peptides were expressed in B. subtilis WB800 cells. Extracellular peptides were purified using a nickel column and tested for their expression by Western blot. The molecular weights of IiR515 (14 kDa) and IiR915 (10 kDa) were observed from a PVDF (Polyvinylidene fluoride) membrane using autoradiography (Figure 5), and we found that the apparent sizes were larger than their predicted sizes. From previous reports, it has been observed 
that the relatively higher isoelectric point, the strong basic charge of the peptides, and the His-tag fusion exert a significant impact on peptide movement in sodium dodecyl sulphate polyacrylamide gel electrophoresis (SDS-PAGE) gels [27]. These results prove that our peptides of interest accumulate in growth media as expected.

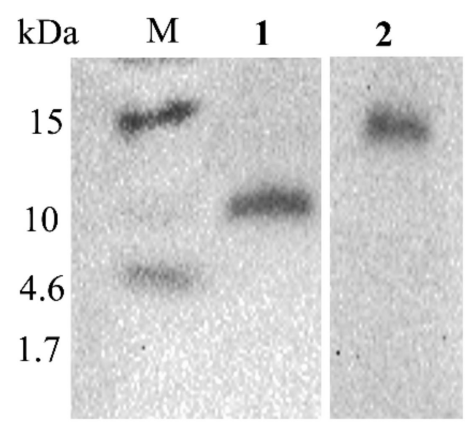

Figure 5. Western blot analysis of fusion peptides.

Autoradiography of IiR515 and IiR915 fusion peptides is shown in Figure 5. Lane M indicates the color prestaining ultra-low molecular weight (1.7-40 kDa) marker. Lane 1 indicates the molecular weight of the full-length IiR915 peptide $(10 \mathrm{kDa})$. Lane 2 indicates the molecular weight of the full-length IiR515 peptide (14 kDa).

\subsection{IiR515 and IiR915 Prevented Phytophthora capsici and Botrytis cinerea Infection on Detached Leaves of Nicotiana benthamiana}

Sensitivity assays using purified IiR515 and IiR915 were performed on detached leaves of $N$. benthamiana under controlled conditions. At $48 \mathrm{~h}$ post-inoculation (hpi), images were taken under normal and ultraviolet (UV) light (Figure $6 a, b$ ). Results indicated a significant percent inhibition of P. capsici compared to the control (Figure 6c). Leaves were infiltrated with $T R V_{2}-I i R 515$ and $T R V_{2}-I i R 915$, and then disks with $B$. cinerea were used to inoculate on the other side of the infiltrated leaves at 48 hpi. Images were taken at $48 \mathrm{~h}$ after fungal inoculation (Figure $6 \mathrm{~d}$ ). The data revealed that IiR515 and IiR915 have the ability to restrict the growth of fungal pathogens (Figure 6e).

\subsection{IiR515- and IiR915-Transformed Bacillus subtilis Inhibited the Growth of Soil-Borne Pathogens}

Anti-soil-borne bacterial assays were applied in simulated soil environments. Plant pathogens were applied to soil treated with transformed B. subtilis. The results showed restricted growth of pathogens in soil treated with the IiR515 and IiR915 strains (Figure 6). We observed that inoculation with the IiR515 strain had a maximum inhibitory effect on C. fangii and C. michiganensis growth on the 2nd and 3rd day, respectively (Figure 6f,h), whereas in the case of the IiR915 strain, maximum restriction of both C. fangii and C. michiganensis was observed on the 1st day (Figure 6g,i).

\subsection{IiR515 and IiR915 Peptides Showed No Significant Hemolytic Activity}

Hemolytic activity assays were performed against sheep blood cells. We found that the hemolysis rates of the IiR515 and IiR915 purified peptides at the extremely high concentration of $1000 \mathrm{mg} / \mathrm{L}$ were $5.3 \%$ and $7.5 \%$, respectively (Table S5). According to our results, no significant hemolytic activity was observed against sheep blood cells. We can likely conclude that these peptides are relatively safe for mammalian cells. 
(a)

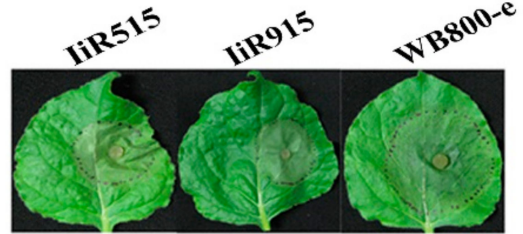

(b)

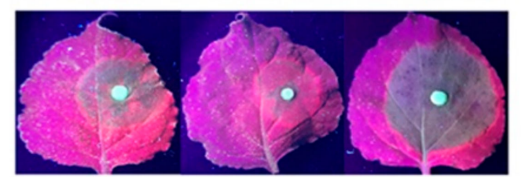

(d)

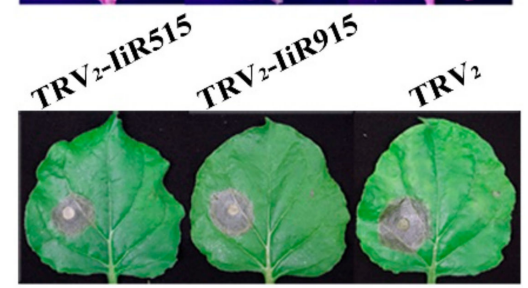

(f)

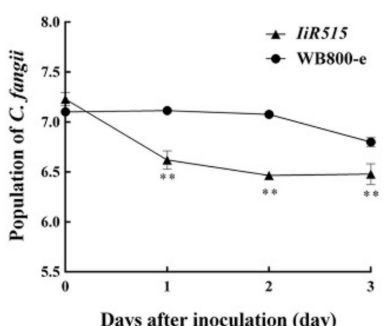

(h)

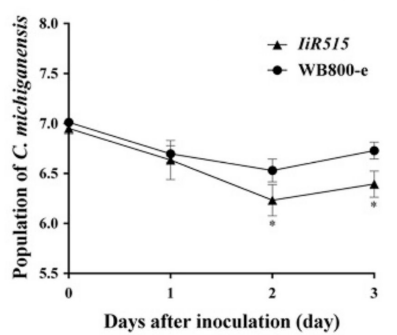

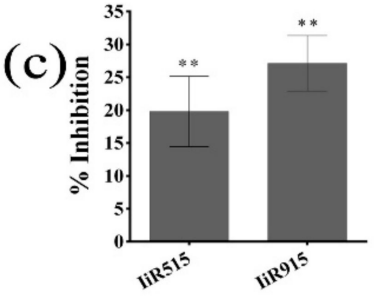

Treatments

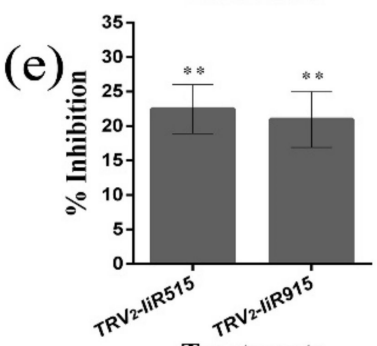

Treatments

(g)

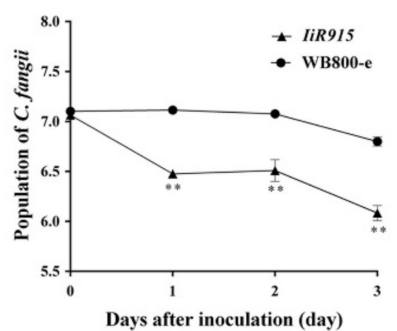

(i)

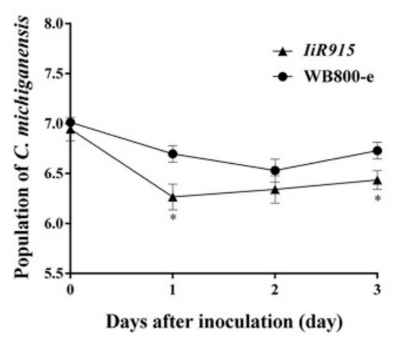

Figure 6. Percent inhibition of Phytophthora capsici and Botrytis cinerea on Nicotiana benthamiana leaves. Images of $P$. capsici disease inhibition (a) under normal light and (b) ultraviolet light $(365 \mathrm{~nm})$. (c) Percent inhibition compared to the control. (d) Images of B. cinerea inhibition and (e) percent inhibition compared with the control. The $y$-axis shows the logarithmic values of the bacterial population (log CFU/10 $\mathrm{g}$ of soil). The inhibitory potential of (f) the IiR515 strain and (g) the IiR915 strain against C. fangii. Inhibitory potential of (h) the IiR515 strain and (i) the IiR915 strain against C. michiganensis compared to the control WB800-e strain. Data are the mean values from three individual experiments. Vertical bars represent the SD. For significance analysis, $t$-tests were performed; ${ }^{*} p<0.05,{ }^{* *} p<0.01$.

\section{Materials and Methods}

\subsection{Plant Materials and Pathogen Cultures}

Isatis indigotica and $N$. benthamiana were grown in nutrient rich soil after pre-germination under controlled greenhouse conditions with $16 / 8 \mathrm{~h}$ light and dark intervals at $25 \pm 3{ }^{\circ} \mathrm{C}$. Bacillus subtilis 330-2 and Xanthomonas oryzae pv. oryzicola RH3 were maintained in the laboratory. B. subtilis WB800 was purchased from Takara Biomedical Technology (Dalian, China). Ralstonia solanacearum R21-5 was procured from the State Key Laboratory of Agricultural Microbiology, Huazhong Agricultural University, Wuhan, Hubei, China. Xanthomonas oryzae pv. oryzae XG-25 was procured from the Hubei Insect Resources Utilization and Sustainable Pest Management Key Laboratory, Huazhong Agricultural University, Wuhan, China. Clavibacter michiganensis subsp. The YCKYBI was procured from the 
Key Lab of Crop Disease Monitoring and Safety Control in Hubei Province, Huazhong Agricultural University, Wuhan, Hubei, China. All bacteria were maintained on Luria-Bertani (LB) media (tryptone, 10.0 g; yeast extract, $5.0 \mathrm{~g} ; \mathrm{NaCl}, 10.0$ g per liter; $\mathrm{pH} 7.0$ ). Clavibacter fangii 1.1999, purchased from the China General Microbiological Culture Collection Center, Beijing, China, was maintained on $0210 \mathrm{R}$ agar media (tryptone, $10.0 \mathrm{~g}$; yeast extract, $5.0 \mathrm{~g}$; malt extract, $5.0 \mathrm{~g}$; casamino acid, $5.0 \mathrm{~g}$; beef extract, $2.0 \mathrm{~g}$; glycerol, $2.0 \mathrm{~g}$; Tween-80, $0.05 \mathrm{~g} ; \mathrm{MgSO}_{4} \cdot 7 \mathrm{H}_{2} \mathrm{O}, 1.0 \mathrm{~g}$; agar, $15.0 \mathrm{~g}$, per liter; $\mathrm{pH} 7.2$ ).

Phytophthora capsici (LT263), procured from the Key Laboratory of Crop Disease Monitoring and Safety Control, Huazhong Agricultural University, Wuhan, Hubei, China, was maintained on V8 media (V8 juice, $100 \mathrm{~mL} ; \mathrm{CaCO}_{3}, 1 \mathrm{~g}$; agar, $17 \mathrm{~g}$ per liter) at $24 \pm 1{ }^{\circ} \mathrm{C}$ under dark conditions. Rhizoctonia solani (AG1-IA) and B. cinerea (B05.10) were maintained on potato dextrose agar (PDA) plates (dextrose, 200 g; agar, 17 g per liter; $\mathrm{pH} 7.0$ ) at $28 \pm 1{ }^{\circ} \mathrm{C}$ and $20 \pm 1^{\circ} \mathrm{C}$, respectively. Caenorhabditis elegans $\mathrm{N}_{2}$ was maintained on nematode growth medium (NGM; tryptone, $2.5 \mathrm{~g}$; NaCl, $3 \mathrm{~g}$; agar, 20 g per liter; pH 7.5; after autoclaving, $1 \mathrm{~mL}$ of $1 \mathrm{M} \mathrm{MgSO}_{4}, 1 \mathrm{~mL}$ of $1 \mathrm{M} \mathrm{CaCl}_{2}, 25 \mathrm{~mL}$ of $1 \mathrm{M} \mathrm{KPO}_{4}$ buffer and $1 \mathrm{~mL}$ of $5 \mathrm{mg} / \mathrm{mL}$ cholesterol were added and mixed well) at $24 \pm 1{ }^{\circ} \mathrm{C}$ with $\mathrm{E}$. coli $\mathrm{OP}_{50}$ as a food source. Further details are displayed in Table S1.

\subsection{Isatis indigotica cDNA Library Construction}

Isatis indigotica leaves were inoculated with $R$. solani. Samples were collected at different time intervals $(6,12,24,30$, and $48 \mathrm{~h})$, immediately frozen in liquid nitrogen, and saved at $-80{ }^{\circ} \mathrm{C}$. Total RNA was extracted by the Trizol method [28]. Next, mRNA was purified from total RNA using the PolyATtract ${ }^{\circledR}$ mRNA isolation system (Promega, Madison, WI, USA). The cDNA library was created using the PrimeScript ${ }^{\mathrm{TM}}$ double-strand cDNA synthesis kit (Takara Biomedical Technology, Dalian, China) with specific oligo dT primers (containing an Xba I cleavage site), followed by linkage to three pairs of adaptors containing Nde I cleavage sites, as previously described [26]. Finally, cDNA products were transformed into B. subtilis WB800 cells. Individual colonies were picked and incubated at $37^{\circ} \mathrm{C}$ overnight. Colony PCR was performed using pBE-S-F (5'-GTTATTTCGAGTCTCTACGG-3') and pBE-S-R (5'-TAACCAAGCCTATGCCTACA-3') primers to confirm the cDNA library quality and then saved at $-80^{\circ} \mathrm{C}$.

\subsection{Candidate Gene Screening and Confirmation}

Initial screening and confirmation were performed as described in a previous study [25]. Briefly, an overnight culture was plated onto fresh LB plates supplemented with kanamycin $(10 \mathrm{mg} / \mathrm{L})$ and incubated at $37^{\circ} \mathrm{C}$ to observe the phenotype. Strains showing cell lysis were selected for the next experiments. Plasmids were extracted from selected strains and transformed into B. subtilis again to reconfirm the gene function in cell lysis.

\subsection{Scanning Electron Microscopy and Cytometric Analysis}

Bacterial cell surface morphology was observed by SEM using previously described methods [29]. Briefly, B. subtilis as test indicator was grown in liquid LB supplemented with kanamycin (10 mg/L) and incubated at $37^{\circ} \mathrm{C}$ for $36 \mathrm{~h}$. Afterwards, bacterial cells were collected by centrifugation at $2500 \times g$ for $3 \mathrm{~min}$. Next, three consecutive washing steps were performed with $20 \mathrm{mmol} / \mathrm{L}$ phosphate buffer saline (PBS; $\mathrm{NaH}_{2} \mathrm{PO}_{4} \cdot 2 \mathrm{H}_{2} \mathrm{O}, 2.6 \mathrm{~g} ; \mathrm{Na}_{2} \mathrm{HPO}_{4} \cdot 12 \mathrm{H}_{2} \mathrm{O}, 29 \mathrm{~g} ; \mathrm{ddH}_{2} \mathrm{O} 500 \mathrm{~mL} ; \mathrm{pH} 7.4$ ). After washing, cells were resuspended in $2.5 \%$ glutaraldehyde and fixed for $2 \mathrm{~h}$, followed by dehydration via an ethanol gradient, with 30\% ethanol, 50\% ethanol, 70\% ethanol, $90 \%$ ethanol, and $100 \%$ ethanol. Dehydrated samples were then dried for 20 min before freeze-drying. Finally, cell samples were lyophilized and gold coated, and observed using a JEOL JSM-7001F scanning electron microscope (Toyama Prefecture, JAPAN).

To observe cell death events, as measured by PI staining, different levels of cell membrane damage of transgenic strains were analyzed on a FACSVerse machine (BD, Franklin Lake, NJ, USA) [30]. Confocal microscopy (Leica microsystems CMS GmbH TCS SP8; Leica, Germany) was also performed 
and cell samples were prepared as previously described [31]. Briefly, the B. subtilis strain was shaken at $37^{\circ} \mathrm{C}$ for $36 \mathrm{~h}$. Bacterial cells were harvested by centrifugation at $1000 \times \mathrm{g}$ for $10 \mathrm{~min}$ and three consecutive washings were performed with $20 \mathrm{mM}$ PBS buffer ( $\mathrm{pH} 7.4$ ), followed by resuspension in the same buffer at $1 \times 10^{9} \mathrm{CFU} / \mathrm{mL}$. Finally, the PI solution was diluted in the cell suspensions to achieve a final concentration of $40 \mathrm{mg} / \mathrm{L}$, and the cells were stained for $30 \mathrm{~min}$ at $4{ }^{\circ} \mathrm{C}$ in the dark. After $30 \mathrm{~min}$, the cells were washed and resuspended in the same volume of PBS buffer, and data were recorded and analyzed with Flowjo.7.6.1.Min (BD, Franklin Lake, NJ, USA).

\subsection{Analysis of Plasma Membrane Fluidity}

To monitor plasma membrane fluidity, the DPH fluorescent probe was prepared and dissolved in tetrahydrofuran (THF) to a final concentration of $200 \mu \mathrm{M}$ [32]. Then, Bacillus cells were collected and washed three times with $20 \mathrm{mmol} / \mathrm{L}$ PBS buffer $\left(\mathrm{Na}_{2} \mathrm{HPO}_{4}, 0.3 \% ; \mathrm{NaH}_{2} \mathrm{PO}_{4}, 0.6 \%, \mathrm{NaCl}, 0.2 \%\right.$; $\left(\mathrm{NH}_{4}\right)_{2} \mathrm{SO}_{4}, 0.8 \%$; $\left.\mathrm{pH} 7.6\right)$. The final concentration of the cell pellets was set to $\mathrm{OD}_{600}$ 0.6. An amount of $2 \mu \mathrm{M}$ DPH was dispersed in PBS and kept for $30 \mathrm{~min}$ at room temperature in the dark and, thereafter, the probe was removed by washing and resuspending in the same buffer. Fluorescence intensity was measured at an excitation wavelength of $365 \mathrm{~nm}$ and an emission wavelength of $425 \mathrm{~nm}$.

\subsection{Measurement of Membrane Potential}

To monitor the membrane electrical potential $(\Delta \Psi)$ of engineered bacteria, a fluorescent probe referred to as 3,3'-dipropylthiadicarbocyanine iodide ( DiSC $_{3}(5)$; OR, USA) was used as previously described, with some modifications [33]. For the measurement of electrical potential gradients across the cytoplasmic membrane of integral cells, excitation wavelengths were set to $622 \mathrm{~nm}$ and emission wavelengths were set to $670 \mathrm{~nm}$. Cells were washed and resuspended in $20 \mathrm{mmol} / \mathrm{L}$ potassium HEPES buffer (HEPES, $20 \mathrm{mM} ; \mathrm{NaCl}, 153 \mathrm{mM} ; \mathrm{KCl}, 5 \mathrm{mM}$; glucose, $5 \mathrm{mM}$; pH 7.4). DiSC $\mathrm{C}_{3}(5)$ was dispersed in HEPES buffer at a final concentration of $5 \mu \mathrm{M}$, and after $3 \mathrm{~min}$ of incubation, cells were washed three times with HEPES buffer, followed by fluorescence intensity measurement with a spectrofluorometer (Shimadzu RF- 5301 PC, Kyoto, Japan).

\subsection{Detection of Cell Membrane Integrity}

To measure cell membrane integrity, we monitored nucleic acid outflow using an Eppendorf Bio Photometer (Hamburg, Germany) [34]. Overnight grown bacteria were inoculated into $50 \mathrm{~mL}$ liquid LB supplemented with kanamycin $(10 \mathrm{mg} / \mathrm{L})$ and shaken at $37^{\circ} \mathrm{C}$. Cell samples were filtrated with $0.22 \mu \mathrm{m}$ filters to remove the bacteria completely. The absorbance of the supernatant was measured at $260 \mathrm{~nm}$ every $2 \mathrm{~h}$.

\subsection{Expression of Crude Proteins}

Extracellular peptides were precipitated using the ammonium sulfate precipitation method with slight modifications [35]. Bacillus subtilis was grown in $200 \mathrm{~mL}$ liquid LB supplemented with kanamycin $(10 \mathrm{mg} / \mathrm{L})$ and incubated at $180 \mathrm{r} / \mathrm{min}, 37^{\circ} \mathrm{C}$ for $72 \mathrm{~h}$. Supernatants were collected by centrifugation at $10,000 \times g, 4{ }^{\circ} \mathrm{C}$ for $20 \mathrm{~min}$. Extracellular peptides were precipitated by adding a saturated ammonium sulfate solution to a final concentration of $50-70 \%$ and stirring continuously on ice for at least $20 \mathrm{~min}$, followed by storage at $4{ }^{\circ} \mathrm{C}$ for $12 \mathrm{~h}$ and then centrifugation to pellet the peptide. The precipitated peptides were dissolved in PBS buffer ( $\mathrm{pH} 7.0$ ) at a concentration of $25 \mathrm{mM}$ and dialyzed in the same PBS buffer for $24 \mathrm{~h}$ at $4{ }^{\circ} \mathrm{C}$. The insoluble debris were discarded by centrifugation using the same conditions previously used.

\subsection{Antimicrobial Activity and Thermal Stability Assays}

Antibacterial activity assays were performed using the previously described disk diffusion method [36]. Briefly, indicator bacteria $\left(10^{8} \mathrm{CFU} / \mathrm{mL}\right)$ were mixed with semisolid NA media and 
poured over previously prepared NA plates. Then, $5 \mathrm{~mm}$ diameter filter paper disks were placed on the agar plates and $20 \mu \mathrm{L}$ of secreted peptides $(1000 \mathrm{mg} / \mathrm{L})$ were added to each filter paper. Thereafter, the Petri dishes were incubated at the different temperatures required for the different indicator bacteria for $12 \mathrm{~h}$. Antibacterial activities were confirmed by measuring the zones of inhibition. For thermal stability tests, the peptides were heated at 50,75 , and $100{ }^{\circ} \mathrm{C}$ for $30 \mathrm{~min}$ before use.

Inhibition assays for B. cinerea was performed as described previously, with slight modifications [37]. Test peptides were prepared as above. Approximately $200 \mu \mathrm{L}$ of peptides were mixed with $4 \mathrm{~mL}$ of semisolid PDA media and poured onto previously prepared PDA plates to a final concentration of $128 \mathrm{mg} / \mathrm{L}$. Then, the plates were seeded with $5 \times 5 \mathrm{~mm}$ mycelial plugs taken from the periphery of three-day-old colonies of B. cinerea (B05.10), followed by incubation at $20^{\circ} \mathrm{C}$. The B. subtilis WB800-e strain was used as a control. Data were recorded at $48 \mathrm{hpi}$. Percent inhibition was calculated according to the following equation: Percent inhibition $(\%)=[($ diameter of control - diameter of treatment)/(diameter of control - diameter of pathogen disk)] $\times 100 \%$.

\subsection{Generation of His-Tag Fusion Peptides}

To purify the IiR515 and IiR915 peptides, His-tag fusion genes were constructed. To add restriction sites at corresponding positions in the coding sequences of IiR515 and IiR915, specific primers were designed (Table S3). Transformation steps were followed based on previously described methods [38]. After transformation, the phenotypes of the cells and their antimicrobial activities were assessed.

\subsection{Purification of Extracellular Peptides}

IiR515 and IiR915 were purified using nickel column affinity chromatography and their antimicrobial activities were confirmed. The fermentation process was carried out as described previously [35]. Briefly, supernatants were collected by centrifugation at $10,000 \times g$ and $4{ }^{\circ} \mathrm{C}$ for $20 \mathrm{~min}$. Thereafter, target peptides were captured using a nickel column at $4{ }^{\circ} \mathrm{C}$, eluted with $600 \mathrm{~nm}$ imidazole, and then concentrated with a $3.5 \mathrm{kDa}$ ultrafiltration tube.

\subsection{Tris-Tricine SDS-PAGE and Western Blotting}

The purified peptide samples were mixed with 2X Tricine-SDS-PAGE Loading Buffer (CWBIO) at a $1: 1$ proportion, heated at $100{ }^{\circ} \mathrm{C}$ for $3-5 \mathrm{~min}$, and centrifuged at $13,000 \times \mathrm{g}$ for $2 \mathrm{~min}$ to remove precipitated impurities. Peptides were separated on a $16.5 \%$ gel and electrophoresed by sodium dodecyl sulphate polyacrylamide gel electrophoresis (SDS-PAGE) with a Tris-Tricine buffer system as described previously [39]. Then, immunoblots were performed with mouse anti-His-tag monoclonal antibody, goat anti-mouse IgG $(\mathrm{H}+\mathrm{L}), \mathrm{HRP}$, and ECL detection reagents. The molecular weights were predicted by comparing with color pre-dyed ultra-low peptide molecular weight marker (Well Biotech, Chungju-si, Korea) [40].

\subsection{Resistance Determination Test}

Resistance tests were performed with detached $N$. benthamiana leaves using a previous method [41]. Uniformly sized leaves were collected and soaked in pure peptides $(100 \mu \mathrm{g} / \mathrm{mL})$, which were pretreated with $0.05 \%$ Silwet L-77, for 3 sec. Bacillus subtilis WB800-e was used as a control. Then, the leaves were inoculated with $5 \times 5 \mathrm{~mm}$ disks of $P$. capsici mycelium and incubated at $25 \pm 3{ }^{\circ} \mathrm{C}$ with high humidity in the dark. Data were recorded at $48 \mathrm{hpi}$ to calculate the percent inhibition according to the following equation: [(control lesion diameter - treatment lesion diameter)/(control lesion diameter - pathogen disk diameter) $] \times 100 \%$.

The IiR515 and IiR915 genes were ligated into the $\mathrm{PTRV}_{2} \mathrm{Ex}$ vector and transformed into Agrobacterium tumefaciens EHA105; they were named $T R V_{2}-I i R 515$ and $T R V_{2}-I i R 915$, respectively. Leaves from uniformly sized $N$. benthamiana plants were selected for infiltration (one side of the leaf) with $T R V_{2}-I i R 515$ and $T R V_{2}-I i R 915$, followed by incubation at $25 \pm 3{ }^{\circ} \mathrm{C}$ with high humidity. The $\mathrm{PTRV}_{2}$ empty vector was used as a control. At $48 \mathrm{hpi}$, infiltrated N. benthamiana leaves were collected and 
inoculated with B. cinerea (other side of the leaf). Data and images were recorded at $48 \mathrm{hpi}$. Percent inhibition was calculated according to the same equation described above.

\subsection{Anti-Soil-Borne Bacteria Assay}

Anti-soil-borne bacteria assays were performed in simulated environments. Sterilized pots were filled with approximately $100 \mathrm{~g}$ of sterilized soil. Then, a $15 \mathrm{~mL}$ amount of fermentation broth was evenly mixed with the prepared soil. Bacillus subtilis WB800-e was used as a control. After $48 \mathrm{~h}$, soil-borne pathogens were prepared at the same concentration $\left(10^{8}\right.$ to $\left.10^{9} \mathrm{CFU} / \mathrm{mL}\right)$, and pretreated soil was inoculated with a total of $15 \mathrm{~mL}$ of pathogen culture. Soil samples were collected at different time intervals $(0,24,48$, and $72 \mathrm{~h}$ ) and $10 \mathrm{~g}$ of soil was mixed with $90 \mathrm{~mL}$ sterilized double distilled water. The mixture was shaken at $180 \mathrm{r} / \mathrm{min}, 28^{\circ} \mathrm{C}$ for $90 \mathrm{~min}$; this was the stock solution for gradient dilutions to obtain an optimum concentration $\left(10^{-5}\right.$ dilution). A total of $100 \mu \mathrm{L}$ of each dilution was taken and spread onto LB plates, followed by incubation at $28^{\circ} \mathrm{C}$. The data were recorded at $24 \mathrm{hpi}$.

\subsection{Hemolytic Activity of IiR515 and IiR915 Peptides}

Hemolytic activity of the IiR515 and IiR915 peptides was assessed using sheep erythrocytes according to previously described methods [42]. Briefly, fresh sheep blood was centrifuged at $600 \times g$ for $10 \mathrm{~min}$ to collect the erythrocytes, then washed three times with PBS buffer (0.2 M, pH 7.2) and resuspended in same solution $(1 \% v / v)$. Different concentrations of pure peptides were diluted with precooled PBS buffer, mixed with isopycnic erythrocyte suspensions in a 96-well cell culture plate and incubated at $37^{\circ} \mathrm{C}$ for $1 \mathrm{~h}$. Thereafter, the cell culture plates were centrifuged at $600 \times g$ for $10 \mathrm{~min}$ and $70 \mu \mathrm{L}$ of the supernatants from each well were collected into a new 96-well cell culture plate. Data were recorded at $540 \mathrm{~nm}$ using a microplate spectrophotometer (xMarK BIO RAD, California USA). An erythrocyte suspension treated with $1 \%$ Triton X-100 was used as a positive control, whereas a suspension incubated with only PBS buffer was used as a negative control. The hemolytic activity percentage was calculated by the following equation: hemolysis $(\%)=\left[\left(\mathrm{OD}_{540}\right.\right.$ peptides $-\mathrm{OD}_{540}$ buffer $) /\left(\mathrm{OD}_{540}\right.$ Triton X-100 - OD 540 buffer $\left.)\right] \times 100 \%$.

\section{Discussion}

There has been increasing interest in the isolation of AMPs in the drug-screening research field recently. In previous studies, scientists have successfully used cDNA libraries for the investigation of protein-protein interactions [43] and the identification of antimicrobial peptides from different organisms [44]. Bacillus subtilis as a host cell facilitates soluble and secretory protein expression, and it is particularly effective for studying the activities of peptides and proteins [45].

For the isolation of novel AMPs, we established a new, sensitive, and high-throughput strategy based on the damaging or killing effects of peptides against B. subtilis host cells [25]. A drawback of this strategy is that strong AMPs will kill B. subtilis cells too rapidly to detect the clones, and therefore, only AMPs with weak killing effects are preferred. However, B. subtilis has a good secretory system, which may reduce the toxicity of strong AMPs. Additionally, during the first few hours $(12 \mathrm{~h})$, the concentration of strong AMPs is possibly not high enough to kill the cells, making the selection of strong AMPs feasible. In our study, part of the B. subtilis system selected AMPs that did not actually show a strong effect on B. subtilis cells; however, the selected AMPs did show strong antimicrobial activity against other pathogens. Although the selection of AMPs with weak killing effects is preferred, the $B$. subtilis screening system has the ability to select for cell membrane-interrupting antimicrobial peptides that inhibit a broad range of pathogens. This strategy was used for the screening of AMPs from the Chinese herbal plant, I. indigotica, which was previously reported for its high antimicrobial activities [46] and other health-related benefits [47]. In this study, we identified 45 different candidates from I. indigotica with the potential to induce autolysis of Bacillus cells. Out of the 45 candidates, two different peptides, IiR515 and IiR915, that exhibited strong antimicrobial activities were selected for further study. These two peptides were considered to be novel because they had no homology in 
NCBI BLAST (National Center for Biotechnology Information and Basic Local Alignment Search Tool) searches or the antimicrobial peptide database (APD) (Figure S4).

Antimicrobial peptides interact with pathogens and enhance their membrane permeability as a killing mechanism [48]; destroying the cell membrane is an efficient way to kill microorganisms [49]. In our study, SEM observations and confocal microscopy images showed cytomembrane damage, including shrinkage, distortion, pore formation, and ruptures. Cytometric analysis of IiR515- and IiR915-transformed Bacillus cells showed the same results and were supported by previous studies [50]. Propidium iodide can penetrate broken cell membranes and cause the majority of cells to emit red fluorescence. Cytomembrane breakage always accompanies intracellular component outflow, such as nucleic acids, which can be detected in the extracellular environment. Cell membrane damages also correlate with membrane fluidity and changes in electrical potential, as our results show. We treated the genomes of different pathogens with these peptides, but they did not cause DNA degradation. Based on our findings, we assume the possible mechanism of the IiR515 and IiR915 peptides was to interrupt or rupture the cell membrane.

Antimicrobial activity tests revealed that the products of our cDNA library contain many antimicrobial peptides, which can directly interact with pathogens. Bacillus subtilis clones exhibiting antimicrobial activities were identified on the basis of the proteins that accumulated inside the cells and caused cell autolysis. Correct guidance by signal peptides can ensure successful secretion of different proteins [51]. Bacillus subtilis 168 is the most popular host for the expression of heterogenous proteins, and it is a biocontrol agent [52] that can secrete many extracellular proteases to degrade extracellular proteins. In contrast, the strain used in this study was B. subtilis WB800, which has mutations in eight key extracellular proteases to reduce the degradation of extracellular proteins [53]. There are several methods that exist for cDNA library construction, which have a significant influence on the experimental results. Many of the methods require PCR amplification to increase the abundance of cDNAs. However, there is a major drawback with these methods, in that a large number of repeated genes are selected in subsequent steps; however, in our present method, PCR amplification is not required to increase the abundance of the cDNA library.

Antimicrobial peptides have been reported to have antimicrobial activities against a diverse range of microorganisms. Both the IiR515 and IiR915 peptides were consistent with previously reported AMPs because of their significant inhibitory effects against Gram-positive and Gram-negative bacteria. Minimum inhibitory concentration for recombinant pBD142 were $100 \mu \mathrm{g} / \mathrm{mL}$ and $80 \mu \mathrm{g} / \mathrm{mL}$ against Escherichia coli and Staphylococcus aureus, respectively. Similarly, the MIC for AMP CAP-1 from Pseudomonas sp. ranged from 30 to $550 \mu \mathrm{g} / \mathrm{mL}$ against a wide range of pathogens [36,54]. Minimum inhibitory concentration for our peptides revealed that they were similar to the previously reported AMPs. However, on the other hand, the inhibition activity of our peptides was not observed as strong as for vancomycin [55]. Phytophthora capsici is a pathogenic oomycete which is hemi-biotrophic and has a broad range of hosts. It can infect most of the Cucurbitaceae and Solanaceae crops [56]. Disks containing P. capsici were used to inoculate N. benthamiana leaves for pathogenicity analysis by observation of necrotic lesions [57]. Our results demonstrated that IiR515 and IiR915 enhanced the resistance of $N$. benthamiana towards $P$. capsici. These two peptides were then ligated into the $\mathrm{pTRV}_{2} \mathrm{Ex}$ (viral vector) vector, and we observed that they had the potential to improve the resistance of $N$. benthamiana towards B. cinerea. Previous studies have shown that the use of viral vectors can produce a huge quantity of AMPs in plant systems to efficiently reduce pathogen attack [58], as was observed in our study.

Antimicrobial peptides exhibit damaging effects against some organisms, but their safety in animals and humans is still an open question [59]. As previously reported, some AMPs have shown low hemolytic activity against mammalian blood cells [1]. In our study, low hemolytic activities were observed at extremely high peptide concentrations. Additionally, different bioassays using C. elegans were performed to assess the toxicity of IiR515 and IiR915 against nematodes [60]. Although the IiR515 and IiR915 peptides have effects on the food tropism of C. elegans, these two peptides did not show 
any killing effect on C. elegans. Furthermore, there were no significant differences in the number of offspring or the body length (Supplementary toxicity assay and Figure S5). Therefore, we speculated that these two peptides obtained from I. indigotica are relatively safe for animal cells and may also be safe for humans. These results indicate the possibility for the application of AMPs to animals and humans in the future.

From the present research, we conclude that the peptides derived from I. indigotica are novel in their functions against different pathogens. These peptides have low molecular weight, a broad antibacterial spectrum, and a good stability against a wide range of temperatures. Furthermore, these peptides also have the ability to destroy the bacterial cell membrane and cell wall structures. On the basis of these distinctive features, future research can be designed for the further characterization of these peptides, followed by the generation of resistance in different crops, as they have already been revealed as potential candidates against pathogens. We hope that, in the future, these peptides can be used as potential raw materials for drug discovery.

Supplementary Materials: The following are available online at http://www.mdpi.com/2218-273X/10/1/30/s1, Figure S1: Quality assessment of total RNA, mRNA, and cDNA, Figure S2: Agarose gel to show cDNA inserts, Figure S3: Antibacterial activity of precipitated peptides against different bacteria performed using an agar diffusion assay, Figure S4: Sequence alignment analysis of IiR515 and IiR915, Figure S5: Peptide secretion assay of IiR515- and IiR915-transformed B. subtilis strains against C. elegans; Table S1: List of strains and vectors used in this study, Table S2: Inhibition of candidate peptides against different microorganisms, Table S3: Primers used to construct His6-IiR915 peptide, Table S4: MICs of IiR515 and IiR915 against different microorganisms, Table S5: Hemolytic activity of IiR515 and IiR915 against sheep blood cells. Supplementary minimum inhibitory concentration (MIC) assay and toxicity assay.

Author Contributions: Conceptualization, J.W., G.W. and W.D.; methodology, J.W., H.M.K.A., J.L. and Y.Y.; validation, J.W., H.M.K.A., J.L., Y.Y. and Y.L.; formal analysis, J.W., G.W. and W.D.; investigation, J.W., H.M.K.A., J.L., Y.Y. and Y.L.; writing-original draft preparation, J.W., H.M.K.A. and W.D.; writing-review and editing, J.W., H.M.K.A., J.L., Y.Y., Y.L., G.W. and W.D.; supervision, G.W. and W.D.; project administration, G.W. and W.D.; funding acquisition, Y.Y. and W.D. All authors have read and agreed to the published version of the manuscript.

Acknowledgments: This work was supported by the National Major Project for Transgenic Organism Breeding (2016ZX08003-001) and the Fundamental Research Funds for the Central Public Welfare Research Institutes (ZZ10-008).

Conflicts of Interest: The authors declare no conflict of interest.

\section{References}

1. Ma, L.; Wang, Y.; Wang, M.; Tian, Y.; Kang, W.; Liu, H.; Wang, H.; Dou, J.; Zhou, C. Effective antimicrobial activity of cbf-14, derived from a cathelin-like domain, against penicillin-resistant bacteria. Biomaterials 2016, 87, 32-45. [CrossRef]

2. Gill, E.E.; Franco, O.L.; Hancock, R.E.W. Antibiotic adjuvants: Diverse strategies for controlling drug-resistant pathogens. Chem. Biol. Drug Des. 2015, 85, 56-78. [CrossRef] [PubMed]

3. Dawson, R.M.; Liu, C.-Q. Properties and applications of antimicrobial peptides in biodefense against biological warfare threat agents. Crit. Rev. Microbiol. 2008, 34, 89-107. [CrossRef] [PubMed]

4. Davies, J.; Davies, D. Origins and evolution of antibiotic resistance. Microbiol. Mol. Biol. Rev. MMBR 2010, 74, 417-433. [CrossRef] [PubMed]

5. Ganewatta, M.S.; Tang, C. Controlling macromolecular structures towards effective antimicrobial. Polymer 2015, 63, A1-A29. [CrossRef]

6. Akaddar, A.; Doderer-Lang, C.; Marzahn, M.R.; Delalande, F.; Mousli, M.; Helle, K.; Van Dorsselaer, A.; Aunis, D.; Dunn, B.M.; Metz-Boutigue, M.H.; et al. Catestatin, an endogenous chromogranin a-derived peptide, inhibits in vitro growth of Plasmodium falciparum. Cell. Mol. Life Sci. CMLS 2010, 67, 1005-1015. [CrossRef]

7. Liang, Q.; Chalamaiah, M.; Ren, X.; Ma, H.; Wu, J. Identification of new anti-inflammatory peptides from zein hydrolysate after simulated gastrointestinal digestion and transport in caco-2 cells. J. Agric. Food Chem. 2018, 66, 1114-1120. [CrossRef] 
8. Seel, W.; Flegler, A.; Zunabovic-Pichler, M.; Lipski, A. Increased isoprenoid quinone concentration modulates membrane fluidity in Listeria monocytogenes at low growth temperatures. J. Bacteriol. 2018, 200, 1-14. [CrossRef]

9. Schroeder, B.O.; Wu, Z.; Nuding, S.; Groscurth, S.; Marcinowski, M.; Beisner, J.; Buchner, J.; Schaller, M.; Stange, E.F.; Wehkamp, J. Reduction of disulphide bonds unmasks potent antimicrobial activity of human beta-defensin 1. Nature 2011, 469, 419-423. [CrossRef]

10. Ramos, R.; Moreira, S.; Rodrigues, A.; Gama, M.; Domingues, L. Recombinant expression and purification of the antimicrobial peptide magainin-2. Biotechnol. Prog. 2013, 29, 17-22. [CrossRef]

11. Ling, L.L.; Schneider, T.; Peoples, A.J.; Spoering, A.L.; Engels, I.; Conlon, B.P.; Mueller, A.; Schaberle, T.F.; Hughes, D.E.; Epstein, S.; et al. A new antibiotic kills pathogens without detectable resistance. Nature 2015, 517, 455-459. [CrossRef]

12. Maria-Neto, S.; de Almeida, K.C.; Macedo, M.L.; Franco, O.L. Understanding bacterial resistance to antimicrobial peptides: From the surface to deep inside. Biochim. Biophys. Acta 2015, 1848, 3078-3088. [CrossRef]

13. Bahar, A.A.; Ren, D. Antimicrobial peptides. Pharmaceuticals 2013, 6, 1543-1575. [CrossRef]

14. Oumer, O.J.; Abate, D. Characterization of pectinase from Bacillus subtilis strain btk 27 and its potential application in removal of mucilage from coffee beans. Enzym. Res. 2017, 2017, 1-6. [CrossRef]

15. Kakeshita, H.; Kageyama, Y.; Endo, K.; Tohata, M.; Ara, K.; Ozaki, K.; Nakamura, K. Secretion of biologically-active human interferon-beta by Bacillus subtilis. Biotechnol. Lett. 2011, 33, 1847-1852. [CrossRef]

16. Schallmey, M.; Singh, A.; Ward, O.P. Developments in the use of Bacillus species for industrial production. Can. J. Microbiol. 2004, 50, 1-17. [CrossRef]

17. Shah, K.; Bhatt, S. Purification and characterization of lipase from Bacillus subtilis pa2. J. Biochem. Tech. 2011, 3, 292-295.

18. Oyeleke, S.B.; Oyewole, O.A.; Egwim, E.C. Production of protease and amylase from Bacillus subtilis and Aspergillus niger using Parkia biglobossa (africa locust beans) as substrate in solid state fermentation. Adv. Life Sci. 2012, 1, 49-53.

19. Li, J.; Zhou, B.; Li, C.; Chen, Q.; Wang, Y.; Li, Z.; Chen, T.; Yang, C.; Jiang, Z.; Zhong, N.; et al. Lariciresinol-4-o-beta-d-glucopyranoside from the root of Isatis indigotica inhibits influenza a virus-induced pro-inflammatory response. J. Ethnopharmacol. 2015, 174, 379-386. [CrossRef]

20. Nguyen, T.K.; Jamali, A.; Grand, E.; Morreel, K.; Marcelo, P.; Gontier, E.; Dauwe, R. Phenylpropanoid profiling reveals a class of hydroxycinnamoyl glucaric acid conjugates in Isatis tinctoria leaves. Phytochemistry 2017, 144, 127-140. [CrossRef]

21. Lin, C.-W.; Tsai, F.-J.; Tsai, C.-H.; Lai, C.-C.; Wan, L.; Ho, T.-Y.; Hsieh, C.-C.; Chao, P.-D.L. Anti-sars coronavirus 3c-like protease effects of Isatis indigotica root and plant-derived phenolic compounds. Antivir. Res. 2005, 68, 36-42. [CrossRef]

22. Ahmad, I.; Fatima, I. Butyrylcholinesterase, lipoxygenase inhibiting and antifungal alkaloids from Isatis tinctoria. J. Enzym. Inhib. Med. Chem. 2008, 23, 313-316. [CrossRef]

23. Camo, C.; Torne, M.; Besalu, E.; Roses, C.; Cirac, A.D.; Moiset, G.; Badosa, E.; Bardaji, E.; Montesinos, E.; Planas, M.; et al. Tryptophan-containing cyclic decapeptides with activity against plant pathogenic bacteria. Molecules 2017, 22, 1817. [CrossRef]

24. Wang, Z.; Wang, Y.; Zheng, L.; Yang, X.; Liu, H.; Guo, J. Isolation and characterization of an antifungal protein from Bacillus licheniformis hs10. Biochem. Biophys. Res. Commun. 2014, 454, 48-52. [CrossRef]

25. Kong, X.; Yang, M.; Abbas, H.M.K.; Wu, J.; Li, M.; Dong, W. Antimicrobial genes from Allium sativum and Pinellia ternata revealed by a Bacillus subtilis expression system. Sci. Rep. 2018, 8, 14514. [CrossRef]

26. Abbas, H.M.K.; Xiang, J.; Ahmad, Z.; Wang, L.; Dong, W. Enhanced Nicotiana benthamiana immune responses caused by heterologous plant genes from Pinellia ternata. BMC Plant Biol. 2018, 18, 357. [CrossRef]

27. Niu, X.; J.Guiltinan, M. DNA binding specificity of the wheat bzip protein embp-1. Nucleic Acids Res. 1994, 22, 4969-4978. [CrossRef]

28. Davis, E.G.; Sang, Y.; Rush, B.; Zhang, G.; Blecha, F. Molecular cloning and characterization of equine nk-lysin. Vet. Immunol. Immunopathol. 2005, 105, 163-169. [CrossRef]

29. Zheng, X.; Wang, X.; Teng, D.; Mao, R.; Hao, Y.; Yang, N.; Zong, L.; Wang, J. Mode of action of plectasin-derived peptides against gas gangrene-associated Clostridium perfringens type A. PLoS ONE 2017, 12, e0185215. [CrossRef] 
30. Lee, H.; Hwang, J.S.; Lee, J.; Kim, J.I.; Lee, D.G. Scolopendin 2, a cationic antimicrobial peptide from centipede, and its membrane-active mechanism. Biochim. Biophys. Acta 2015, 1848, 634-642. [CrossRef]

31. Teng, D.; Wang, X.; Xi, D.; Mao, R.; Zhang, Y.; Guan, Q.; Zhang, J.; Wang, J. A dual mechanism involved in membrane and nucleic acid disruption of AvBD103b, a new avian defensin from the king penguin, against Salmonella enteritidis CVCC3377. Appl. Microbiol. Biotechnol. 2014, 98, 8313-8325. [CrossRef]

32. Jacquet, T.; Cailliez-Grimal, C.; Francius, G.; Borges, F.; Imran, M.; Duval, J.F.; Revol-Junelles, A.M. Antibacterial activity of class IIa bacteriocin Cbn BM1 depends on the physiological state of the target bacteria. Res. Microbiol. 2012, 163, 323-331. [CrossRef]

33. Castellano, P.; Raya, R.; Vignolo, G. Mode of action of lactocin 705, a two-component bacteriocin from Lactobacillus casei CRL705. Int. J. Food Microbiol. 2003, 85, 35-43. [CrossRef]

34. Patra, P.; Mitra, S.; Goswami, A.; Roy, S.; Pradhan, S.; Sarkar, S.; Debnath, N. Damage of lipopolysaccharides in outer cell membrane and production of ros-mediated stress within bacteria makes nano zinc oxide a bactericidal agent. Appl. Nanosci. 2015, 5, 857-866. [CrossRef]

35. Wang, H.; Yang, X.; Guo, L.; Zeng, H.; Qiu, D. Pebl1, a novel protein elicitor from Brevibacillus laterosporus strain a60, activates defense responses and systemic resistance in Nicotiana benthamiana. Appl. Environ. Microbiol. 2015, 81, 2706-2716. [CrossRef]

36. Yin, M.; Liu, D.; Xu, F.; Xiao, L.; Wang, Q.; Wang, B.; Chang, Y.; Zheng, J.; Tao, X.; Liu, G.; et al. A specific antimicrobial protein CAP-1 from Pseudomonas sp. isolated from the jellyfish Cyanea capillata. Int. J. Biol. Macromol. 2016, 82, 488-496. [CrossRef]

37. Zhou, F.; Zhang, X.-L.; Li, J.-L.; Zhu, F.-X. Dimethachlon resistance in Sclerotinia sclerotiorum in china. Plant Dis. 2014, 98, 1221-1226. [CrossRef]

38. Anagnostopoulos, C.; Spizizen, J. Requirements for transformation in Bacillus subtilis. J. Bacteriol. 1961, 81, 741-746.

39. Wen, L.S.; Philip, K.; Ajam, N. Purification, characterization and mode of action of plantaricin K25 produced by Lactobacillus plantarum. Food Control 2016, 60, 430-439. [CrossRef]

40. Wang, S.; Wang, Q.; Zeng, X.; Ye, Q.; Huang, S.; Yu, H.; Yang, T.; Qiao, S. Use of the antimicrobial peptide sublancin with combined antibacterial and immunomodulatory activities to protect against methicillin-resistant Staphylococcus aureus infection in mice. J. Agric. Food Chem. 2017, 65, 8595-8605. [CrossRef]

41. Xu, L.; Xiang, M.; White, D.; Chen, W. Ph dependency of sclerotial development and pathogenicity revealed by using genetically defined oxalate-minus mutants of Sclerotinia sclerotiorum. Environ. Microbiol. 2015, 17, 2896-2909. [CrossRef]

42. Mohanram, H.; Bhattacharjya, S. 'Lollipop'-shaped helical structure of a hybrid antimicrobial peptide of temporin b-lipopolysaccharide binding motif and mapping cationic residues in antibacterial activity. Biochim. Biophys. Acta 2016, 1860, 1362-1372. [CrossRef]

43. Tang, X.; Shi, J.; Dong, W. A yeast library-hybrid assay to screen maize-Rhizoctonia transcription factors and protein-protein interactions in one experimental pipeline. Agri Gene 2016, 1, 15-22. [CrossRef]

44. Kumaresan, V.; Bhatt, P.; Ganesh, M.R.; Harikrishnan, R.; Arasu, M.; Al-Dhabi, N.A.; Pasupuleti, M.; Marimuthu, K.; Arockiaraj, J. A novel antimicrobial peptide derived from fish goose type lysozyme disrupts the membrane of Salmonella enterica. Mol. Immunol. 2015, 68, 421-433. [CrossRef]

45. Westers, L.; Westers, H.; Quax, W.J. Bacillus subtilis as cell factory for pharmaceutical proteins: A biotechnological approach to optimize the host organism. Biochim. Biophys. Acta 2004, 1694, $299-310$. [CrossRef]

46. Seifert, K.; Unger, W. Insecticidal and fungicidal compounds from Isatis Tinctoria. Z. Nat. 1994, 49c, 44-48. [CrossRef]

47. Xiao, P.; Huang, H.; Chen, J.; Li, X. In vitro antioxidant and anti-inflammatory activities of Radix isatidis extract and bioaccessibility of six bioactive compounds after simulated gastro-intestinal digestion. J. Ethnopharmacol. 2014, 157, 55-61. [CrossRef]

48. Hao, G.; Shi, Y.-H.; Tang, Y.-L.; Le, G.-W. The intracellular mechanism of action on Escherichia coli of bf2-a/c, two analogues of the antimicrobial peptide buforin 2. J. Microbiol. 2013, 51, 200-206. [CrossRef]

49. Haversen, L.; Kondori, N.; Baltzer, L.; Hanson, L.A.; Dolphin, G.T.; Duner, K.; Mattsby-Baltzer, I. Structure-microbicidal activity relationship of synthetic fragments derived from the antibacterial alpha-helix of human lactoferrin. Antimicrob. Agents Chemother. 2010, 54, 418-425. [CrossRef] 
50. Park, Y.; Kim, H.J.; Hahm, K.S. Antibacterial synergism of novel antibiotic peptides with chloramphenicol. Biochem. Biophys. Res. Commun. 2004, 321, 109-115. [CrossRef]

51. Ling Lin, F.; Zi Rong, X.; Wei Fen, L.; Jiang Bing, S.; Ping, L.; Chun Xia, H. Protein secretion pathways in Bacillus subtilis: Implication for optimization of heterologous protein secretion. Biotechnol. Adv. 2007, 25, 1-12. [CrossRef]

52. Barbe, V.; Cruveiller, S.; Kunst, F.; Lenoble, P.; Meurice, G.; Sekowska, A.; Vallenet, D.; Wang, T.; Moszer, I.; Medigue, C.; et al. From a consortium sequence to a unified sequence: The Bacillus subtilis 168 reference genome a decade later. Microbiology 2009, 155, 1758-1775. [CrossRef]

53. Wu, S.C.; Yeung, J.C.; Duan, Y.; Ye, R.; Szarka, S.J.; Habibi, H.R.; Wong, S.L. Functional production and characterization of a fibrin-specific single-chain antibody fragment from Bacillus subtilis: Effects of molecular chaperones and a wall-bound protease on antibody fragment production. Appl. Environ. Microbiol. 2002, 68, 3261-3269. [CrossRef]

54. Li, C.L.; Xu, T.T.; Chen, R.B.; Huang, X.X.; Zhao, Y.C.; Bao, Y.Y.; Zhao, W.D.; Zheng, Z.Y. Cloning, expression and characterization of antimicrobial porcine beta defensin 1 in Escherichia coli. Protein Exp. Purif. 2013, 88, 47-53. [CrossRef]

55. Musta, A.C.; Riederer, K.; Shemes, S.; Chase, P.; Jose, J.; Johnson, L.B.; Khatib, R. Vancomycin MIC plus heteroresistance and outcome of methicillin-resistant Staphylococcus aureus bacteremia: Trends over 11 Years. J. Clin. Microbiol. 2009, 47, 1640-1644. [CrossRef]

56. Lamour, K.H.; Stam, R.; Jupe, J.; Huitema, E. The oomycete broad-host-range pathogen Phytophthora capsici. Mol. Plant Pathol. 2012, 13, 329-337. [CrossRef]

57. Lai, G.; Fu, P.; Liu, Y.; Xiang, J.; Lu, J. Molecular characterization and overexpression of VpRPW8s from Vitis pseudoreticulata enhances resistance to Phytophthora capsici in Nicotiana benthamiana. Int. J. Mol. Sci. 2018, 19, 839. [CrossRef]

58. Zeitler, B.; Meyer, H.; Bernhard, A.; Sattler, M.; Lindermayr, C. Production of a de-novo designed antimicrobial peptide in Nicotiana benthamiana. Plant Mol. Biol. 2013, 81, 259-272. [CrossRef]

59. Rammelkamp, C.H.; Weinstein, L. Toxic effects of tyrothricin, gramicidin and tyrocidine. J. Infect. Dis. 1942, 71, 166-173. [CrossRef]

60. Ali, M.; Sun, Y.; Xie, L.; Yu, H.; Bashir, A.; Li, L. The pathogenicity of Pseudomonas syringae mb03 against Caenorhabditis elegans and the transcriptional response of nematicidal genes upon different nutritional conditions. Front. Microbiol. 2016, 7, 1-12. [CrossRef] 